\title{
KAJIAN TEMATIK AIR PADA SIKLUS AIR MENURUT PERSPEKTIF SAINS DAN AL-QURAN
}

\author{
Muhammad Maslan $^{1 *}$, Ahmad Muzakki ${ }^{2}$, Maharani Retna Duhita ${ }^{1}$, \\ Hafsan $^{3}$ \\ ${ }^{1}$ Program Studi Magister Biologi \\ Fakultas Sains dan Teknologi UIN Maulana Malik Ibrahim \\ Jl. Gajayana No. 50, Kota Malang, Jawa Timur. 65145 \\ "E-mail: 200602210011@ student.uin-malang.ac.id \\ ${ }^{2}$ Departemen Biologi \\ Fakultas Sains dan Teknologi UIN Maulana Malik Ibrahim \\ Jl. Gajayana No. 50, Kota Malang, Jawa Timur. 65145 \\ ${ }^{3}$ Jurusan Biologi \\ Fakultas Sains dan Teknologi UIN Alauddin Makassar \\ Jl. Sultan Alauddin No. 63, Kabupaten Gowa, Sulawesi Selatan. 92113
}

\begin{abstract}
Abstrak: Allah SWT menurunkan al-Qur'an sebagai pedoman hidup manusia. Proses penciptaan alam adalah kekuatan Tuhan dalam menciptakan kehidupan. Allah menciptakan alam semesta yaitu langit dan bumi sebagai sarana kehidupan bagi makhluk hidup khususnya manusia. Dia menciptakan dunia ini memiliki maksud dan tujuan tertentu dengan kebenaran. Seperti ciptaan alam (air) yang memiliki manfaat bagi makhluk hidup. Tujuan dari penelitian ini adalah untuk menjelaskan mukjizat ayat-ayat al-Qur'an. Hasilnya adalah ayat tentang air yang berperan dalam siklus air yang disebut Al-Quran adalah air laut ada 33 kali, air dari langit (hujan) 32 kali dan air sungai sebanyak 48 kali, lalu siklus air dalam kebenaran ayat-ayat al-Qur'an adalah kekuasaan Allah. Jadi sebagai seorang Muslim yang beriman, ia telah menjadikan al-Qur'an sebagai pelajaran dan kekuatan iman dan pedoman hidup dalam Islam sebagai ilmuwan besar. Ilmu pengetahuan memudahkan umat Islam untuk memahami isi al-Qur'an.
\end{abstract}

Kata Kunci: Al-Qur'an, sains, siklus air

\section{PENDAHULUAN}

$\mathrm{N}$

abi Muhammad saw. datang membawa kebenaran ilmiah di tengah bangsa arab yang terbelakang dan tak berilmu. Empat belas abad kemudian, riset ilmiah mengungkapkan kebenaran islam. Padahal, al-Qur'an tidak diturunkan sebagai kitab ilmu kedokteran, ilmu falak (astronomi) ataupun ilmu sains lainnya. Namun, para ilmuwan di berbagai bidang berhasil menyingkap mukjizat ilmiah al-Qur'an. Kemukjizatan al-Qur'an tampak jelas dalam keindahan aspek bahasa dan sastranya, pemberitaannya tentang umat terdahulu maupun peristiwa masa depan, serta hikmah dibalik syariat ditetapkannya. Kini, perbincangan seputar mukjizat ilmiah al-Qur'an kian penting seiring dengan perkembangan pesat ilmu pengetahuan (Thayyarah, 2014). Sebagai ilmuan muslim sudah menjadi al-Quran sebagai pedoman sebagai dasar ilmu pengetahuan. Allah telah menorehkan Firman-Nya secara jelas dan tersirat mengenai kekuasaan penciptaan alam (langit dan bumi) serta seluruh isinya dalam al-Quran. Sebagai hambanya (manusia) di anjurkan untuk mengkaji dan mengimplementasikan isiNya, karena kebenaran tidak diragukan lagi yang mempunyai peranan dan fungsi bagi 
kehidupan dari zaman dahulu, perkembangan zaman dengan kecanggihan teknologi hingga akhir zaman nantinya.

Penciptaan alam adalah suatu kekuasaan Tuhan dalam menciptakan kehidupan. Allah menciptakan Alam semesta yaitu langit dan bumi sebagai fasilitas hidup untuk makhluk hidup utamanya ada manusia. DiciptakanNya alam ini mempunyai Maksud dan tujuan tertentu dengan benar adanya. Salah satu kejadian alam yang termasuk kemukjizatan atau keajaiban dalam al-Quran yaitu fenoman air hujan, yang dimana banyak ilmuan atau peneliti baru di ungkapkan modern ini. Hal ini ini air hujan banyak dipelajari dalam sains sebagai dasar ilmu ekologi yang dimana interaksi atau hubungan manusia, makhluk hidup dengan lingkungan dikenal yaitu siklus air. Siklus air sangat berperan dalam kelangsungan kehidupan dan kesetimbangan alam mulai hewan dan tumbuhan, semuanya terjadi adanya siklus yang merupakan putaran waktu yang di dalamnya terdapat daur/rangkaian kejadian yang berulang-ulang secara tetap dan teratur.

Dari kesetimbangan kehidupan tersebut siklus air (siklus hidrologi) ini sangat berperan utama bagi kehidupan. Air merupakan senyawa kimia Yang terdapat di alam sebagai senyawa esensial baik manusia, hewan, maupun tumbuhan. Sehingga Air mempunyai peran baik dalam fungsi biologis, ekologis, sosial ekonomi dan sumber dalam alam. Air menurut pandangan agama (Islam) bahwa air merupakan unsur atau elemen utama yang terlebih dahulu diciptakan Tuhan sebelum menciptakan kehidupan di bumi. Dengan air maka segala sesuatu di bumi ini menjadi hidup (Mawardi, 2014). Karena Allah telah menciptakan air dan menetapkannya sebagai asal muasal kehidupan sebagaimana firmanNya: "...Kami jadikan segala sesuatu yang hidup berasal dari air" (QS. al-Anbiyaa/21:30). Berdasarkan hal tersebut ini akan akan mengkaji bagaimana siklus air secara tematik dalam sains dan alquran dengan manfaat air bagi kehidupan. Tujuan dari penelitian ini untuk menjelaskan kumujizatan al-Quran tentang siklus air hujan dan penjelasan persfektif sains secara tematik.

\section{METODE PENELITIAN}

Penelitian ini telah dibentuk menggunakan penelitian pustaka atau berbagai sumber literatur sebagai sumber data penelitian, baik penelitian Perpustakaan atau riset. Metode digunakan dengan pendekatan penafsiaran sains dan al-Quran, hal ini bersifat deskriptif. Batasan penelitian ini adalah menetukankan judul dalam al Qur'an, menjelaskan proses silklus air secara tematik, dan mengumpulkan kemudian menetapkan ayat yang mebahas tentang air hujan secara berurutan berdasarkan susanan al-Quran. Maka studi ini butuhakan penafsiran dari beberbagi diskusi atau bahasan baik pemikitan seorang tokoh, ulama, buku dan pemahaman masyakat masalah tersebut yakni library research yang mengandalkan atau memakai sumber karya tulis kepustakaan (Sawaluddin, 2018).

\section{HASIL DAN PEMBAHASAN}

Adapun penafsiran air dalam peran siklus air seperti laut, air dari langit dan air sungai dalam ayat-ayat al-Quran ditunjukkan pada Tabel 1-3.

Tabel 1. Surah dan ayat al-Quran yang mengandung kalimat air laut

\begin{tabular}{cccccc}
\hline No. & Surah & Ayat & No. & Surah & Ayat \\
\hline 1 & al-Baqarah & 164 & 18 & al-Furqan & 53 \\
2 & al-maidah & 96 & 19 & Asy-Syuura & 32 \\
3 & al-An'am & 63 & 20 & al-Naml & 61 \\
4 & al-A'raf & 138 & 21 & al-Qasas & 40 \\
5 & al-A'raf & 136 & 22 & Ar-Ruum & 41
\end{tabular}




\begin{tabular}{cccccc}
6 & Yunus & 90 & 23 & Luqman & 27 \\
7 & Ibrahim & 32 & 24 & Luqman & 31 \\
8 & al-Nahl & 14 & 25 & Fatir & 12 \\
9 & Al-Israa, & 69 & 26 & al-Jatsiyah & 12 \\
10 & al- Israa & 66 & 27 & Az-Zaariat & 40 \\
11 & al-Kahfi & 60 & 28 & Ath-Thuur & 6 \\
12 & al-Kahfi & 109 & 29 & al-Rahman & 19 \\
13 & Thaahaa & 77 & 30 & al-Rahman & 24 \\
14 & Thaahaa & 78 & 31 & al-Rahman & 20 \\
15 & Thaahaa & 97 & 32 & al-Rahman & 32 \\
16 & al-Hajj & 65 & 33 & at-Takwir & 6 \\
17 & al-Nur & 40 & & & \\
\hline
\end{tabular}

Tabel 2. Surah dan ayat al-Quran yang mengandung kalimat air hujan

\begin{tabular}{llllll}
\hline No. & Surah & Ayat & No. & Surah & Ayat \\
\hline 1 & al-Baqarah & 22 & 17 & al- Hajj & 63 \\
2 & al-Baqarah & 164 & 18 & al-Mukminun & 18 \\
3 & al-An'am & 99 & 19 & al-Furqan & 48 \\
4 & al-A'raf & 57 & 20 & al-Namal & 60 \\
5 & al-Anfal & 11 & 21 & al-'Ankabut & 63 \\
6 & Yunus & 24 & 22 & al-'Ankabut & 24 \\
7 & Hud & 7 & 23 & Luqman & 10 \\
8 & Hud & 44 & 24 & al-Sajdah & 27 \\
9 & Ibrahim & 32 & 25 & Fatir & 27 \\
10 & al-Hijr & 22 & 26 & al-Zumar & 21 \\
11 & al-Nahl & 10 & 27 & Fusilat & 39 \\
12 & al-Nahl & 65 & 28 & Al-Zuhruf & 11 \\
13 & al-Kahfi & 45 & 29 & Qaaf & 9 \\
14 & Taha & 53 & 30 & al-Qamar & 11 \\
15 & al-Anbiya' & 30 & 31 & al- Naba & 14 \\
16 & al- Hajj & 5 & 32 & 'Abasa & 25 \\
\hline
\end{tabular}

Tabel 3. Surah dan ayat al-Quran yang mengandung kalimat air sungai

\begin{tabular}{|c|c|c|c|c|c|}
\hline No. & Surah & Ayat & No. & Surah & Ayat \\
\hline 1 & al-Baqarah & 25 & 25 & Thaahaa & 7 \\
\hline 2 & al-Baqarah & 74 & 26 & Thaahaa & 37 \\
\hline 3 & al-Baqarah & 266 & 27 & Thaahaa & 76 \\
\hline 4 & al-Imran & 15 & 28 & al-Hajj & 14 \\
\hline 5 & al-Imran & 136 & 29 & al-Hajj & 23 \\
\hline 6 & al-Imran & 195 & 30 & al-Furqan & 10 \\
\hline 7 & al-Imran & 198 & 31 & al-Ankabut & 58 \\
\hline 8 & al-Nisa & 13 & 32 & al-Zumar & 20 \\
\hline 9 & al-Nisa & 57 & 33 & al-Zukhruf & 51 \\
\hline 10 & al-Nisa & 122 & 34 & Muhammad & 12 \\
\hline 11 & al-Maidah & 12 & 35 & Muhammad & 15 \\
\hline 12 & al-Maidah & 85 & 36 & al-Fath & 5 \\
\hline 13 & al-Maidah & 119 & 37 & al-Fath & 17 \\
\hline 14 & al-An'am & 6 & 38 & al-Hadid & 12 \\
\hline 15 & al-A'raf & 43 & 39 & al-Mujadalah & 22 \\
\hline 16 & al-Taubah & 72 & 40 & al-Shaf & 22 \\
\hline 17 & al-Taubah & 89 & 41 & al-Taghabun & 9 \\
\hline 18 & al-Taubah & 100 & 42 & al-Talaq & 11 \\
\hline 19 & Yunus & 9 & 43 & al-Tahrim & 8 \\
\hline 20 & al-Ra'd & 35 & 44 & al-Buruj & 11 \\
\hline 21 & al-Ra'd & 3 & 45 & al- Bayyinah & 8 \\
\hline 22 & Ibrahim & 23 & 46 & al-Nahl & 115 \\
\hline 23 & Ibrahim & 32 & 47 & al-Naml & 61 \\
\hline
\end{tabular}


Berdasarkan Tabel 1-3 bahwa ayat-ayat tentang air dari langit, laut dan sungai sangat berperan dalam kehidupan alam hal ini juga dalam sains berperan dalam proses siklus air yang disebut siklus Hidrologi. Siklus air atau siklus hidrologi adalah pergerakan dan perubahan air didalam hidrosfer (Indarto, 2014). Siklus ini merupakan pengulangan proses turunnya hujan. Karena sifat air yang mudah berubah wujud seperti cair, padat, dan gas. Perubahan wujud air ini bisa disebabkan banyak hal, seperti paparan sinar matahari dan perubahan musim. Air yang berada didaratan seperti laut, danau, dan sungai yang terpapar sinar mentari mengalami perubahan wujud menjadi gas atau mengalami penguapan. Kemudian naik ke udara dan berubah menjadi awan dan mengalami perubahan wujud kembali menjadi cair dan turun sebagai hujan. Proses tersebut terus mengalami pengulangan. Terus terjadi berulang-ulang mulai dari proses penguapan air didaratan, pembentukkan awan, turunnya hujan, hingga menguap Kembali (Abdillah, 2019).

Air hujan dan laut dan sungai saling berkaitan dalam proses siklus. Menurut Eskandar et al (2012), sebuah sungai, atau aliran, terbentuk setiap kali air bergerak menuruni bukit dari satu tempat ke tempat lain. Ini berarti sebagian besar sungai terbentuk jauh di pegunungan, tempat salju atau gletser kuno mencair. Itu sungai selalu mengalir menuruni bukit. Dalam perjalanan/ menurun dan akhirnya berakhir di laut, air dikumpulkan dari hujan dan lainnya aliran.

Air merupakan hasil turunnya hujan dari atmosfer ke permukan bumi baik dalam bentuk es, salju, ataupun bentuk cair. Hal ini berdasarkan dalam Q.S. Al-Baqarah/2: 22 dan al-A'raaf/7:57 gambaran proses turunnya hujan.

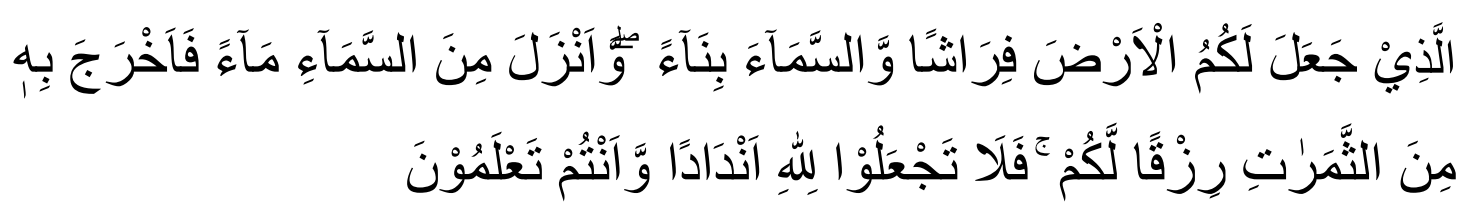

Terjemahnya:

(Dialah) yang menjadikan bumi sebagai hamparan bagimu dan langit sebagai atap, dan Dialah yang menurunkan air (hujan) dari langit, lalu Dia hasilkan dengan (hujan) itu buah-buahan sebagai rezeki untukmu. Karena itu, janganlah kamu mengadakan tandingan-tandingan bagi Allah, padahal kamu mengetahui (Kementrian Agama RI, 2013: 4).

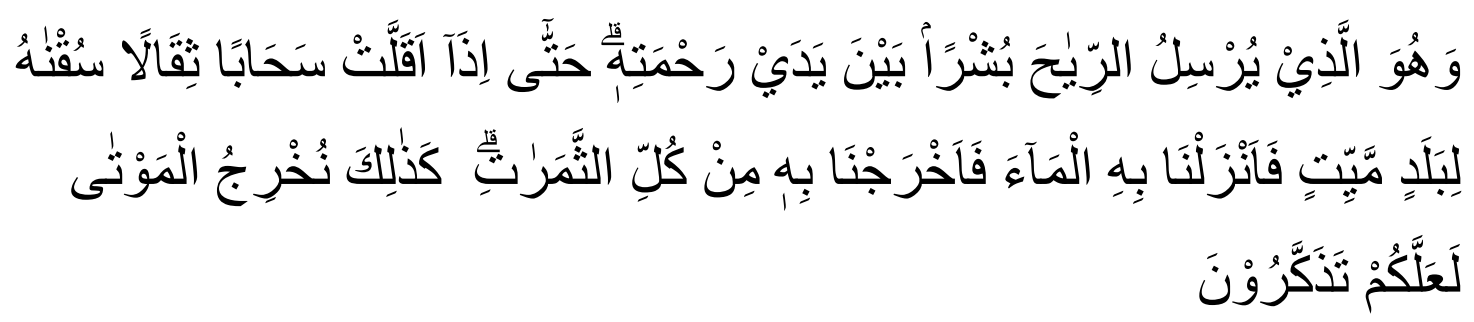

Terjemahnya:

Dialah yang meniupkan angin sebagai pembawa kabar gembira, mendahului kedatangan rahmat-Nya (hujan), sehingga apabila angin itu membawa awan mendung, Kami halau ke suatu daerah yang tandus, lalu Kami turunkan hujan di daerah itu. Kemudian Kami tumbuhkan dengan hujan itu berbagai macam buah-buahan. Seperti itulah Kami 
membangkitkan orang yang telah mati, mudah-mudahan kamu mengambil pelajaran (Kementrian Agama RI, 2013: 157).

Pada proses turunnya hujan menurut 2 ayat tersebut meggambarkan bahwa hamparan bumi dan langit sebagai atap dikatakan suatu atmosfer, kemudian angin sebagai pembawa kabar gembira artinya adanya awan menuju ke daerah yang tandus artinya daerah kering, atau tidakada tumbuhan tanaman karena unsur hara dan termasuk daerah beku seperti bersalju/es. Sehingga awan itu di halau untuk turunnya ait hujan ke bumi, maka air hujan itu di manfaatkan makhluk hidup di bumi seperti tumbuh-tumbuhan, hewan dan manusia. Pada Tumbuhan menghasilkan berbagai macam baik buah-buahan, biji-bijian dan tanaman lain, hal ini adalah rezeki pemberian Tuhan yang Mahapemurah dan kuasa kepada Makhluk lainnya baik dimnafaatkan manusia atau ternak. Selain itu air hujan akan akan menyerap ke dalam tanam, dan mengalir membentul sungai dari daratan tinggi (gunung) menuju ke daerah rendah kemudian terkumpul yaitu terbentuk danau dan air laut. Maka semua proses tersebut adalah kekuasaan Allah yang tidak tandingan hal ini kemukjizat al-Quran dibandingan manusia hanya mengambil pelajaran.

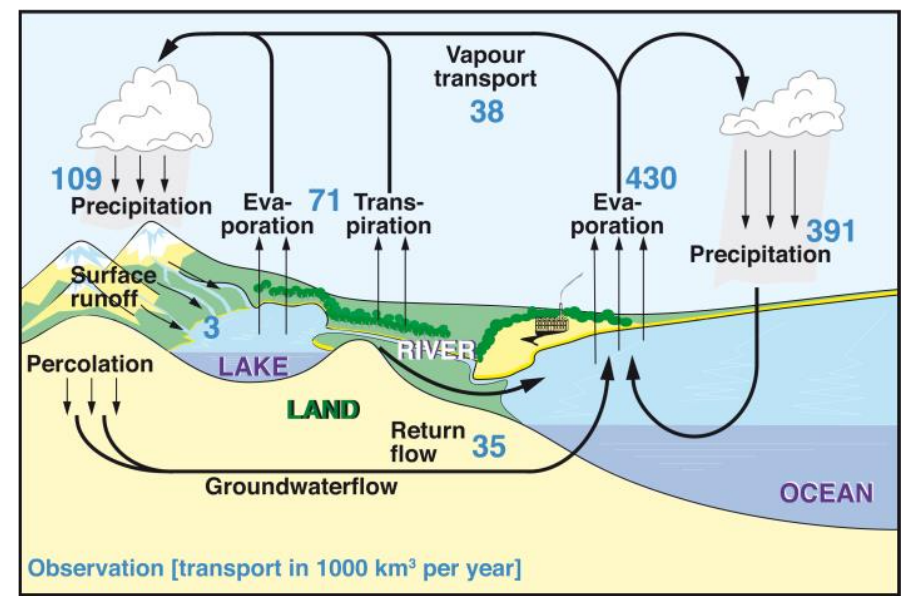

Gambar 1. Siklus air global mengikuti Baumgartner dan Reichel (1975) dalam Lennart, 2010

Berdasarkan Gambar 1, menurut Eskandar et al (2012), air di sungai dan danau menguap sementara tanaman keluar air s(transpire) selama fotosintesis. Air yang menguap dibawa ke atmosfer untuk menghasilkan awan yang kemudian mengembun di atmosfer yang lebih dingin, melepaskan air kembali ke bumi dalam bentuk hujan atau presipitasi.

Menurut Bayong (2012), Lennart (2010), dan Watanabe (2011), proses turunnya hujan sendiri berturut-turut diawali dengan proses penguapan air di permukaan bumi. Hidrosfer sendiri adalah daerah dimana terdapat air baik di atmosfer maupun di permukaan bumi. Evaporation merupakan perubahan wujud air dari wujud cair menjadi gas atau uap. Transpiration adalah sebuah proses terangkatnya air di dalam permukaan tanah oleh akar tumbuhan dan selanjutnya diuapkan. Sublimation adalah proses konversi langsung dari es dan salju menjadi uap air. Condentation adalah perubahan wujud air dari bentuk gas atau uap menjadi bentuk padat atau cair biasa disebut awan. Presipitation (endapan) adalah bentuk air cair (hujan) atau bentuk air padat (salju) yang jatuh sampai permukaan tanah. Infiltrasi adalah gerakan air ke bawah melalui permukaan tanah ke dalam profil tanah.

Air merupakan salah satu kebutuhan dasar bagi setiap makhluk hidup, utamanya adalah manusia. Dapat dipastikan manusia tidak akan mampu bertahan 
hidup tanpa air, karena air merupakan salah satu elemen dasar yang menunjang proses metabolisme tubuh manusia. Dalam tubuh manusia sendiri terdiri dari $70-90 \%$ air. Adapaun beberapa manfaat air lainnya (Mawardi, 2014):

1. Dalam Islam digunakan untuk membersihkan atau bersuci (Wudhu);

2. Menunjang dalam pembentukan bumi dalam geologi;

3. Keperluan rumah tangga, misalnya untuk minum, masak, mandi, cuci dan pekerjaan lain-lainnya;

4. Keperluan umum, misalnya untuk kebersihan jalan dan pasar, pengangkutan air limbah, hiasan kota, tempat rekreasi dan lain-lainnya;

5. Keperluan industri, misalnya untuk pabrik dan bangunan pembangkit tenaga lainlainnya;

6. Keperluan perdagangan, misalnya untuk hotel, restoran, dan yang lainya; dan

7. Keperluan pertanian dan peternakan. keperluan pelayaran Misalkan sebagai jalur transportasi dan lain sebagainya.

\section{KESIMPULAN}

Allah menciptakan segala sesuatu atas kekuasaan Tuhan yang Maha Besar, Maha Penyayang lagi Maha Pengasih saeperti penciptan alam (air) yang mempunyai manfaat bagi kehidupan makhluk Hidup. Ayat al-Quran yang menyebutkan tentang air laut ada 33 kali, air dari langit (hujan) ada 32 kali dan air sungai sebayak 48 kali. Maka siklus air dalam kebenaran al-Quran sebagai muslim yang beriman sudah menjadikan pelajaran dan suatu kekuatan iman dalam Islam. Ilmu sains memudahkan dalam memahami Quran.

\section{DAFTAR PUSTAKA}

Abdillah, I.A.S. (2019). Fenome Hujan Dalam Al-quran. [Skripsi]. Lampung: UIN Raden Intan.

Bayong, T.H.K. (2012). Mikrofisika Awan dan Hujan. Jakarta: Badan Meteorologi Klimatologi dan Geofisika.

Bengtsson, L. (2010). The Global Atmospheric Water Cycle. Environmental Research Letters, 5, 1-8. doi:10.1088/1748-9326/5/2/025002

Eskandar, H., Sadollah, A., Bahreininejad, A., \& Hamdi, M. (2012). Algoritme Siklus Air-Metode Optimasi Metaheuristik Baru Untuk Memecahkan Masalah Pengoptimalan Teknik Yang Dibatasi. Journal Elsevier Computers and Structures, 110-111. doi: doi.org/10.1016/j.compstruc.2012.07.010.

Imamudin, M. (2012). Peranan Air Dalam Perspektif Al-Quran. El-hayah, 3(1), 41-45.

Indarto. (2014). Hidrologi. Jakarta: Bumi Aksara.

Kementerian Agama Republik Indonesia. (2013). al-Quran dan Terjemahnya. Jakarta: Kementerian Agama Republik Indonesia.

Mawardi, M. (2014). Air dan Masa Depan Kehidupan. Jurnal Tarjih Volume 12 (1), 131-142.

Mustakim. (2017). Pendidikan Lingkungan Hidup dan Implementasinya Dalam Pendidikan Islam (Analisis Surat Al-a'raf Ayat 56-58 Tafsir Al Misbah Karya M. Quraish Shihab). Journal of Islamic Education (JIE), 2(1), 1-27.

Sasongko, E.B., Widyastuti, E., Priyono, R.E. (2014). Kajian Kualitas Air dan Penggunaan Sumur Gali Oleh Masyarakat di Sekitar Sungai Kaliyasa Kabupaten Cilacap. Jurnal Ilmu Lingkungan, 12, 2, 7282

Sawaluddin \& Sainab. (2018). Air Dalam Persepektif Al-Quran dan Sains. Jurnal Tarbiyah: Jurnal Ilmiah Kependidikan, 7(2), 109-122.

Susana, T. (2003). Air Sebagai Sumber Kehidupan. Oseana, 28(3). 17-25.

Thayyarah, N. (2014). Buku Pintar Sains dalam Al-Qur'an. Jakarta: Zaman.

Watanabe., Marcos, D.B., \& Ortega, E. (2011). Ecosystem Services and Biogeochemical Cycles on A Global Scale: Valuation of Water, Carbon and Nitrogen Processes. Elsevier Journal Enviromental Science and Policy, 1(4), 594-604. 